\title{
PERANCANGAN APLIKASI MOBILE "MANDALUNGAN" SEBAGAI LAYANAN ONLINE POLRES KABUPATEN BREBES
}

\author{
Godham Eko Saputro ${ }^{1}$, Toto Haryadi ${ }^{2}$ \\ 1,2Program Studi Desain Komunikasi Visual, Fakultas Ilmu Komputer \\ Universitas Dian Nuswantoro, Jl. Imam Bonjol No. 207 Semarang, 50131 \\ ${ }^{1}$ godham.eko@gmail.com, ${ }^{2}$ toto.haryadi@dsn.dinus.ac.id
}

\begin{abstract}
Abstrak: Kabupaten Brebes yang terletak di pantai utara Jawa (Pantura) memiliki penduduk yang banyak serta wilayah yang luas, sehingga harus dikondisikan aman dan kondusif oleh pemerintah daerah setempat. Walaupun patroli intens dilakukan oleh Polres dan Kodim, diharapkan masyarakat peduli dan pro aktif melaporkan gangguan keamanan dan ketertiban masyarakat melalui saluran yang mudah dan bertanggungjawab. Belum adanya media yang menghubungkan pihak pemerintah daerah tersebut dengan masyarakat, menyebabkan komunikasi antar kedua pihak tersebut tidak efektif dan efisien. Di era saat ini, aplikasi menjadi media yang tepat untuk mengatasi masalah di atas. Tujuan penelitian ini adalah merancang aplikasi layanan masyarakat untuk mempercepat pelaporan tindak kejahatan serta pusat informasi warga Brebes agar segera ditangani oleh Polres, 17 Polsek, dan Pemda Brebes. Metode penelitian ini menggunakan pendekatan kualitatif dan perancangan aplikasi ini menggunakan metode MDLC. Hasil dari penelitian ini adalah aplikasi bernama MANDALUNGAN yang dapat di download gratis untuk membantu menurunkan gangguan kamtibmas serta menjadi harapan ideal masyarakat terhadap kinerja Pemerintah daerah.
\end{abstract}

Kata kunci: Aplikasi, Brebes, Layanan Masyarakat, Mandalungan

Abstract: Brebes Regency which is located on the north coast of Java "(Pantura)" has a large population and a wide area, must be conditioned safely and conducive by the local government. Although intense patrols are carried out by the Polres and Kodim, it is hoped that a careful and proactive community will report the disorder of the public security through a channel which is easy and responsible. No media which connects the Brebes government with the public leads the communication for them becomes ineffective and inefficient. In this era, application becomes the right medium to solve abovementioned problem. The purpose of this study is to design a community service application to accelerate crime reporting and to become the Brebes citizen information center so that it is immediately handled by the District Police Office, 17 Sector Police Offices and the Brebes Regional Government. This research method used a qualitative approach and the 
design of this application used the MDLC method. The result of this study is an application called MANDALUNGAN which can be downloaded for free to help reducing the disorder of the public order and becoming an ideal hope of the community towards the performance of the local government.

Keywords: Application, Brebes, Public Service, Mandalungan

\section{PENDAHULUAN}

Brebes seperti yang dilansir brebeskab.go.id merupakan kabupaten yang terletak di bagian utara paling barat Provinsi Jawa Tengah dan di mana sebagian besar wilayahnya berupa dataran rendah dan dataran tinggi dengan puncaknya Gunung Pojok Tiga dan Gunung Kumbang. Data jumlah penduduk Brebes menurut data terbaru (Semester 1 tahun 2019) dari dindukcapil.brebeskab.go.id mencapai 1.917.918 jiwa.

Dengan cukup luasnya wilayah Kabupaten Brebes dan berada di wilayah Pantura (Pantai Utara Jawa) serta banyaknya penduduk, penegak hukum setempat harus memastikan kondisi Kamtibmas yang aman dan kondusif agar masyarakat terjamin aktivitasnya dari aksi kejahatan. RRI telah mencatat Polres Brebes bersama Kodim 0713 dan Sub Denpom IV/1-4 Brebes melakukan berbagai terobosan, salah satunya adalah razia dan patroli malam. Walaupun aparat keamanan intens melakukan patroli, masyarakat juga harus bersikap peduli dan proaktif melaporkan adanya tindak kejahatan (Suprianto, 2019).

Di era revolusi industri 4.0 ini, Internet of Things (IOT) memegang peranan penting karena memudahkan manusia dalam berkomunikasi melalui perangkat dan jaringan. Walau Indonesia belum tergolong negara maju tetapi mayoritas warganya memiliki smartphone. Pew Research Center melakukan survey di 27 negara bulan Mei sampai Agustus 2018 dengan melibatkan 30.133 responden, hasilnya adalah 42 persen orang dewasa di Indonesia memiliki smartphone, 28 persen mempunyai ponsel biasa, dan 29 persen tidak memiliki ponsel. Paparan di 
atas menyimpulkan bahwa smartphone sudah menjadi perangkat yang umum digunakan masyarakat, dengan beragam fitur dan hiburan memanfaatkan serta memaksimalkan penggunaannya (Alfarizi dan Yanuar, 2019).

Terkait keamanan, sebuah smartphone dapat dimanfaatkan masyarakat untuk melaporkan gangguan Kamtibmas. Selama ini bila terjadi kejahatan, respon tercepat adalah menggunakan Call Center 110 yang langsung terhubung ke petugas kepolisian. Kelemahan Call Center adalah banyak telepon iseng dan salah sambung yang tentunya merugikan petugas. Selain itu, belum terdapat upaya tindakan yang responsif, realtime, serta bisa melibatkan masyarakat kapan pun dan dimana pun untuk mendorong pihak Polres dan Pemda Brebes selaku pengelola kabupaten untuk menciptakan sebuah media komunikasi visual yang benar-benar bisa mengakomodasi kebutuhan masyarakat berkaitan dengan pelayanan kepolisian setempat.

Terlebih hal ini ditunjang dengan semakin mutakhirnya fitur foto, audio, dan video dalam smartphone maka perlu adanya terobosan baru untuk layanan pelaporan seperti kejahatan, kecelakaan, kerusuhan, pengaduan, bahkan layanan informasi. Polri sebagai garda terdepan keamanan memiliki program Promoter (profesional, modern, dan terpercaya). Definisi "modern" memiliki makna melakukan modernisasi dalam layanan publik yang didukung teknologi sehingga semakin mudah dan cepat diakses oleh masyarakat. Sedangkan salah satu komitmen Polri adalah berkoordinasi dengan stakeholder terkait untuk memudahkan dan melancarkan program yang ada, dalam hal ini stakeholder yang dipilih adalah Pemda Brebes. Berdasarkan permasalahan tersebut, aplikasi berbasis smartphone menjadi media komunikasi visual yang diyakini efektif dan efisien dalam memberikan pelayanan lebih baik dan cepat sebagai sarana komunikasi langsung dua arah antara petugas Polres dan Pemda Brebes dengan masyarakat sekitar. 
Aplikasi mobile merupakan dua istilah yang digabungkan menjadi satu. Aplikasi yaitu program siap pakai untuk kebutuhan tertentu, sedangkan mobile yaitu berpindah dari satu tempat ke tempat lain, yang berarti aplikasi mobile merupakan aplikasi yang dipasang di perangkat mobile (Siregar dan Permana, 2016). Aplikasi juga merupakan program siap pakai yang dapat digunakan untuk menjalankan perintah-perintah dari pengguna aplikasi tersebut dengan tujuan mendapatkan hasil yang lebih akurat sesuai dengan tujuan pembuatan aplikasi tersebut (Abdurahman dan Riswaya, 2014). Aplikasi yang terpasang di smartphone atau lebih dikenal sebagai aplikasi mobile merupakan aplikasi yang khusus dijalankan pada perangkat mobile seperti smartphone dan tablet sebagai penunjang aktivitas pengguna serta meningkatkan fleksibilitas (Razi, Mutiaz, dan Setiawan, 2018).

Maraknya pemanfaatan aplikasi mobile yang semakin luas di bidang pendidikan, kesehatan, lalu lintas, pelestarian tradisi, dan lain sebagainya juga menjadi faktor pendukung pentingnya keberadaan aplikasi mobile saat ini. Sebagai contoh dalam bidang pendidikan, aplikasi dimanfaatkan untuk mensimulasikan pembelajaran melukis bangun ruang untuk kelas $X$ sebagai media penunjang pembelajaran mandiri (Rokhman, 2018). Contoh lainnya yaitu penelitian menghasilkan prototype komik interaktif berwujud aplikasi mobile untuk mengkampanyekan safety riding secara digital yang ditujukan pada remaja (Saputro, Haryadi, dan Yanuarsari, 2016). Aplikasi mobile "Mandalungan" ini merupakan terobosan baru baik bagi pihak Polres, peneliti, maupun masyarakat. Hal ini dikarenakan belum ada yang meneliti masalah ini, serta pelayanan yang diberikan Polres masih bersifat konvensional. Melalui aplikasi ini, masyarakat dimudahkan untuk melapor, memberikan informasi, serta melakukan aktivitas yang berkaitan dengan pelayanan Polres dan Pemda Brebes secara efektif dan efisien. Selain itu, aplikasi ini merupakan aplikasi pertama yang digunakan oleh Aparatur Sipil Negara (ASN) Kabupaten Brebes sebagai upaya mengikuti 
perkembangan teknologi khususnya di era Revolusi Industri 4.0 yang didukung dengan konsep Internet of Thing (IoT).

\section{METODE PENELITIAN}

Penelitian ini menggunakan metode kualitatif, yakni pendekatan yang fokus mengeksplorasi dan mendalami suatu permasalahan secara umum, serta melibatkan pandangan, pengetahuan, dan pemikiran peneliti dalam memahami obyek penelitian (Raco, 2010). Penelitian ditunjang dengan metode pengumpulan data pengamatan langsung dilakukan di Kabupaten Brebes yang merupakan daerah pesisir atau Pantura di mana memiliki karakteristik lebih terbuka terhadap dunia luar karena menjadi urat nadi utama transportasi darat di Jawa. Dampaknya adalah cepat terjadi asimilasi kebudayaan, bila masyarakat tidak bisa memilahmilah hal yang baik dan buruk, sangat berpotensi meningkatkan kejahatan.

Selain itu, penulis menggunakan metode studi pustaka sebagai acuan dasar perancangan. Penulis menggunakan studi pustaka yang bersumber pada buku, jurnal, dan internet terkait aplikasi mobile dan program kerja Polres Brebes beserta informasi pendukung. Metode wawancara juga telah dilakukan penulis. Informasi verbal dan literatur dirasa kurang cukup, sehingga penulis melakukan wawancara langsung dengan Bripda Zaky Mubarok selaku anggota Reskrim Polres Brebes.

Perancangan aplikasi mobile dalam penelitian ini menggunakan metode Multimedia Development Life Cycle (MDLC). Metode ini merupakan salah satu metode yang digunakan untuk mengembangkan project berbasis multimedia interaktif yang dicetuskan oleh Luther-Sutopo dengan enam tahapan, yakni: Concept merupakan identifikasi tujuan, target audiens, serta bentuk aplikasi yang akan dirancang; Design merupakan tahap spesifikasi aplikasi yang akan dirancang yaitu program, gaya, dan tampilan; Material Collecting fokus pada pengumpulan 
aset yang diperlukan dalam aplikasi berupa teks, gambar, foto, audio, dan sebagainya; Assembly merupakan pembuatan aplikasi menggunakan software untuk mengorganisasikan aset yang dipilih; Testing yaitu menguji aplikasi secara personal maupun melibatkan orang lain; dan Distribution merupakan tahap terakhir untuk publikasi secara luas (Binanto, 2010). Metode ini merupakan pengembangan dari metode Waterfall yang telah ditemukan pada tahun 1995 (Binanto, 2013). Multimedia merupakan gabungan dari elemen-elemen teks, gambar, audio, video, dan sebagainya (Vaughan, 2004).

Penelitian sebelumnya yang menggunakan metode MDLC dalam perancangan game simulasi "Warungku" yakni game desktop pengenalan makanan khas Jawa Tengah (Haryadi dan Aripin, 2015). Game dan aplikasi sebagai bentuk multimedia interaktif melibatkan elemen teks, visual, audio, sentuhan (touchscreen) sehingga lebih maksimal dibanding media lain karena melibatkan tiga indera yakni: indera mata, telinga, dan peraba (Haryadi, 2016).

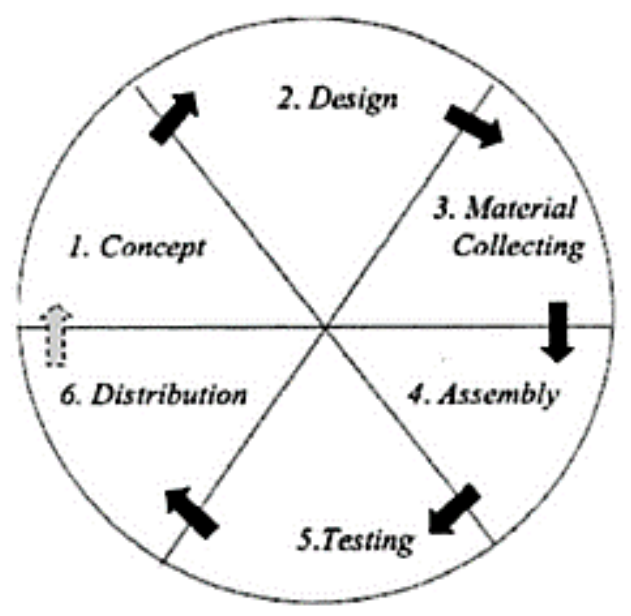

Gambar 1. Tahapan Metode MDLC Luther-Rustopo Sumber: Binanto (2010:260) 


\section{HASIL PERANCANGAN DAN DISKUSI}

Perancangan aplikasi mobile dimulai dari tahap Concept hingga Distribution. Setiap tahapan menjelaskan bagian-bagian dari aplikasi mulai dari informasi dasar hingga proses perancangannya tahap demi tahap. Setiap tahapan dijelaskan dalam tabel sehingga mudah dipahami setiap prosesnya.

Pada tahap Concept (konsep), berisi informasi dasar tentang aplikasi yang dirancang mencakup apa nama aplikasi, untuk apa aplikasi dibuat, siapa target audiensnya, serta bagaimana bentuk aplikasinya.

Tabel 1 Concept aplikasi hasil penelitian

\begin{tabular}{ll}
\hline Nama aplikasi & "MANDALUNGAN" yang merupakan akronim dari "Aman \\
& Terkendali Layanan Untuk Panjenengan" \\
\hline Tujuan perancangan & Menjadi layanan PROMOTER Polres Brebes dan Pemda \\
& Brebes kepada masyarakat untuk mempercepat pelaporan \\
& tindak kejahatan dan kriminalitas dari warga Brebes agar \\
& bisa segera ditangani \\
\hline Target audiens & warga Kabupaten Brebes berusia 17 - 50 tahun yang bisa \\
& mengoperasikan perangkat smartphone \\
\hline Bentuk aplikasi & Aplikasi berbasis mobile (multimedia interaktif) \\
& multiplatform
\end{tabular}

sumber : Saputro dan Haryadi, 2020

Tahap berikutnya yaitu Design (rancangan). Design ini bukan ke eksekusi aplikasi, tetapi lebih fokus pada informasi lanjutan tentang aplikasi yang dirancang, yakni: platform apa yang digunakan, perangkat apa yang digunakan untuk mengaksesnya, gaya visual seperti apa yang digunakan, serta tone and manner yang dipilih seperti apa.

Tabel 2 Penjabaran tahap Design dalam perancangan aplikasi mobile

\begin{tabular}{ll}
\hline Program platform & $\begin{array}{l}\text { Aplikasi ini dirancang menggunakan IDE Eclipse berbasis Java } \\
\text { programming }\end{array}$ \\
\hline Perangkat akses & Smartphone dan tablet PC dengan Android OS \\
\hline Gaya visual/tampilan & Layout dengan penataan menu model bar/line \\
\hline Tone and manner & $\begin{array}{l}\text { Flat design dengan penggunaan satu warna untuk tombol } \\
\text { navigasi }\end{array}$ \\
\hline & sumber : Saputro dan Haryadi, 2020
\end{tabular}


Setelah tahap Design dilalui, tahap berikutnya yaitu Material Collecting (pengumpulan aset). Aset-aset yang digunakan dalam aplikasi mobile ini terdiri dari teks, gambar, layout, hingga user interface yang dibutuhkan. Dari aset yang dibutuhkan, penulis merancang sketsa komprehensif dari model tampilan aplikasi sebagai acuan dalam tahap digitalisasi. Selain itu, pada tahapan ini penulis melakukan pendataan ke Polres dan Pemda untuk memperoleh nomor WhatsApp personil masing-masing sesuai bidangnya, yang akan diinput ke aplikasi. Tahap ini merupakan tahap tersulit karena berbenturan dengan birokrasi.

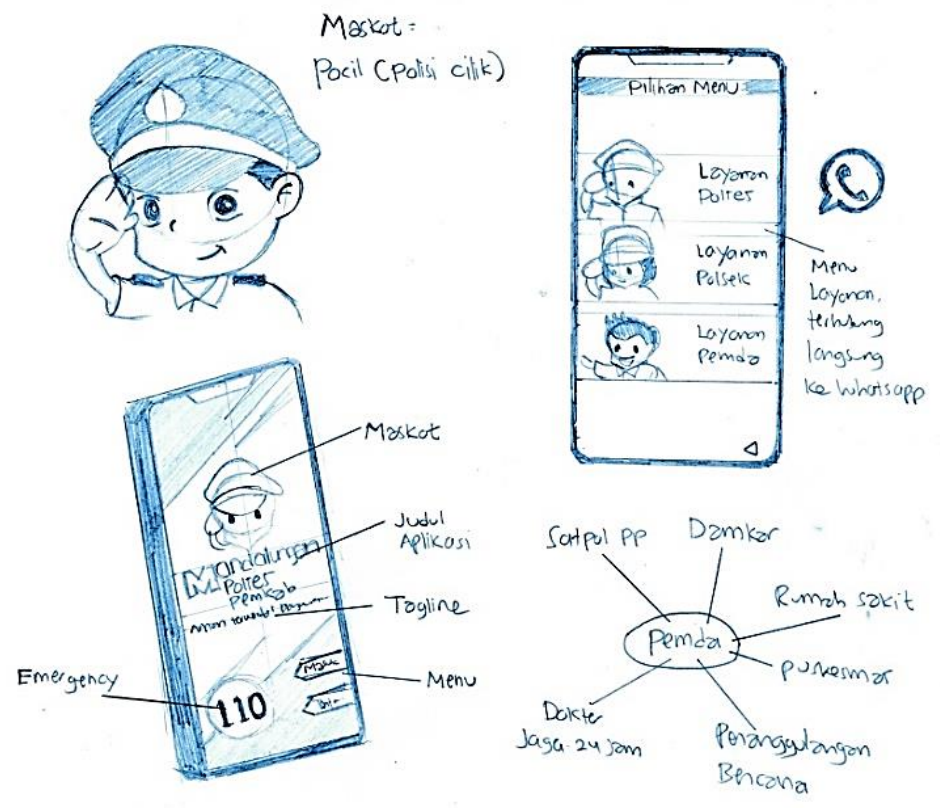

Gambar 2. Sketsa komprehensif aplikasi Sumber: Saputro dan Haryadi, 2020

Gambar 2 di atas menunjukkan hasil brainstorming bahwa aplikasi "Mandalungan" yang dibutuhkan memuat akses berupa: Layanan Polres, Layanan Polsek, serta Layanan Pemda, yang di-breakdown secara lebih detail. Sebagai identitas, di awal aplikasi perlu ditampilkan maskot kepolisian, nama aplikasi, serta 
layanan cepat berupa nomor emergency call 110. Aset-aset yang dibutuhkan kemudian dikembangkan secara digital (Gambar 3).

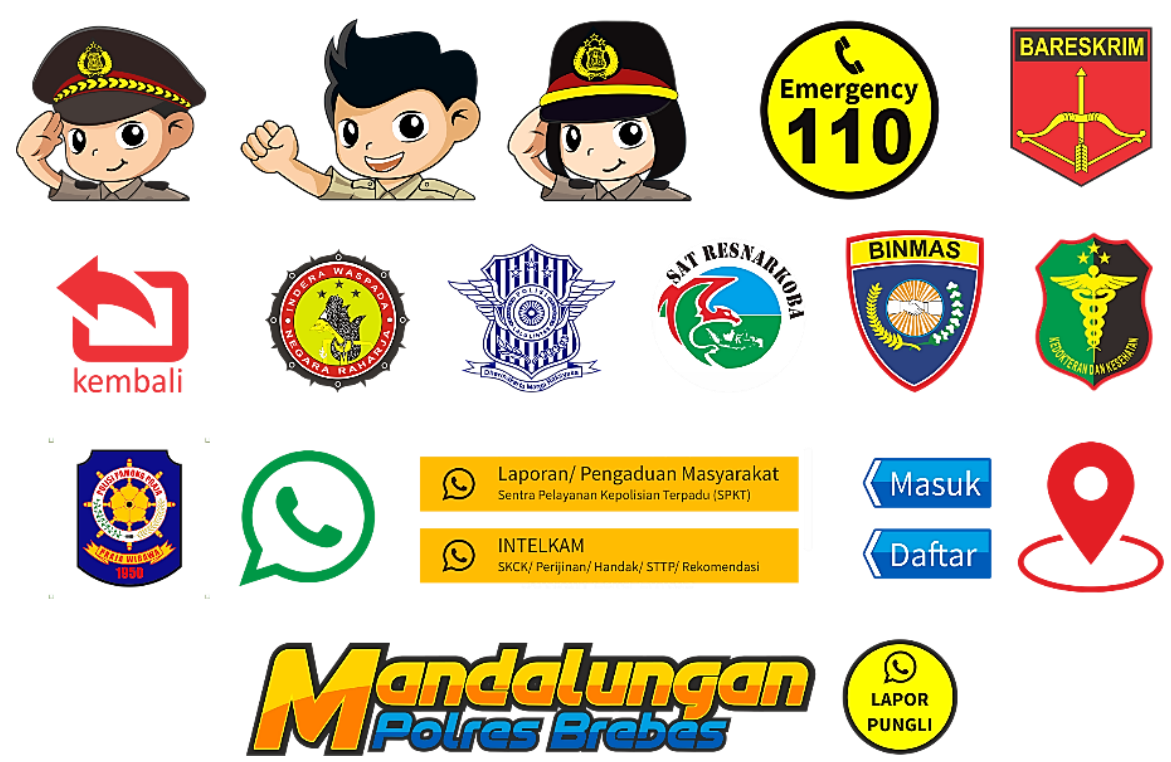

Gambar 3. Digitalisasi aset yang dibutuhkan dalam aplikasi Sumber: Saputro dan Haryadi, 2020

Aset yang telah dirancang hingga tahap digital diproses untuk tahap selanjutnya yakni assembly (pembuatan aplikasi). Pembuatan aplikasi ini menggunakan IDE Eclipse berbasis Java sebagai bahasa programming yang bersifat open source. Karena smartphone dengan android OS cukup akrab di tangan masyarakat, maka sementara ini aplikasi dikembangkan di perangkat yang mendukung OS tersebut. Menu utama yang tersaji dalam aplikasi ini yaitu: Layanan Polres Brebes, Polsek Brebes, dan Pemda Brebes. Layanan Polres Brebes langsung terhubung WhatsApp ke semua satuan seperti Reserse Kriminal, Intelijen Keamanan, Lalu Lintas, Reserse Narkoba, Sie Propam, Pembina Masyarakat, dan Ur Dokkes. Layanan Polsek langsung terhubung ke semua nomor WhatsApp 17 Polsek di wilayah Brebes unit pengaduan masyarakat, Intelkam, Reskrim, Sabhara, 
dan Binmas. Sedangkan Layanan Pemda Brebes langsung terhubung ke nomor WhatsApp Satpol PP, Damkar, Rumah sakit, Puskesmas, Penanggulangan bencana dan Dokter jaga 24 jam.
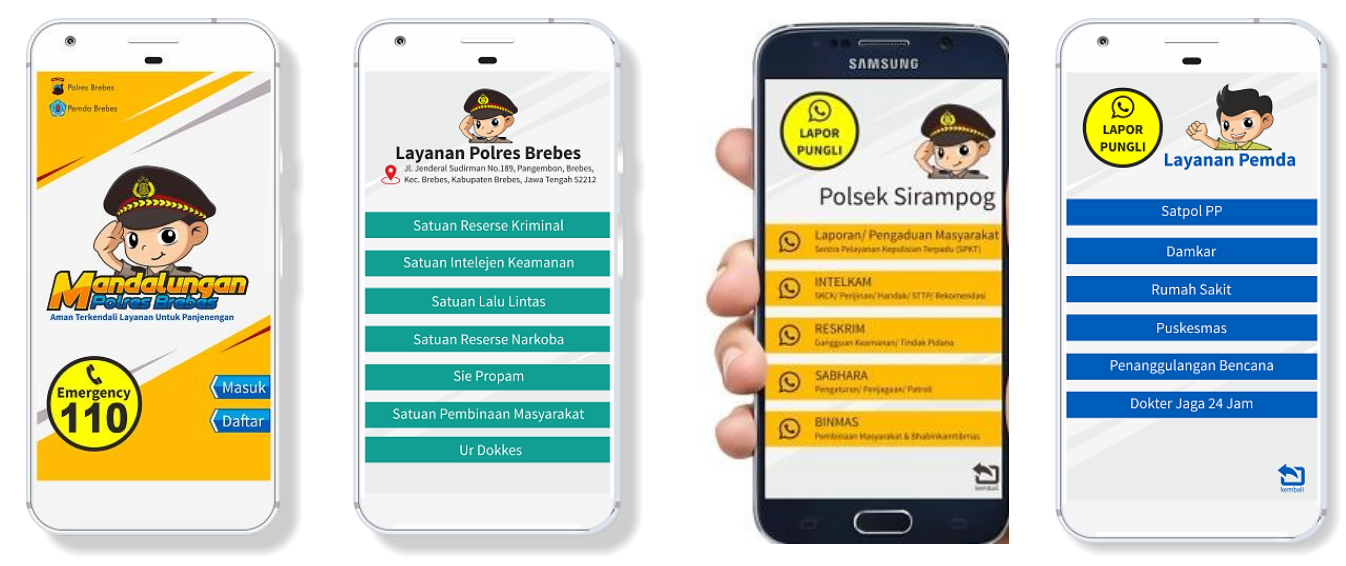

Gambar 4. Tampilan Menu Utama (kiri ke kanan):

Tampilan Utama, Layanan Polres Brebes, Layanan Polsek, dan Layanan Pemda Sumber: Saputro dan Haryadi, 2020
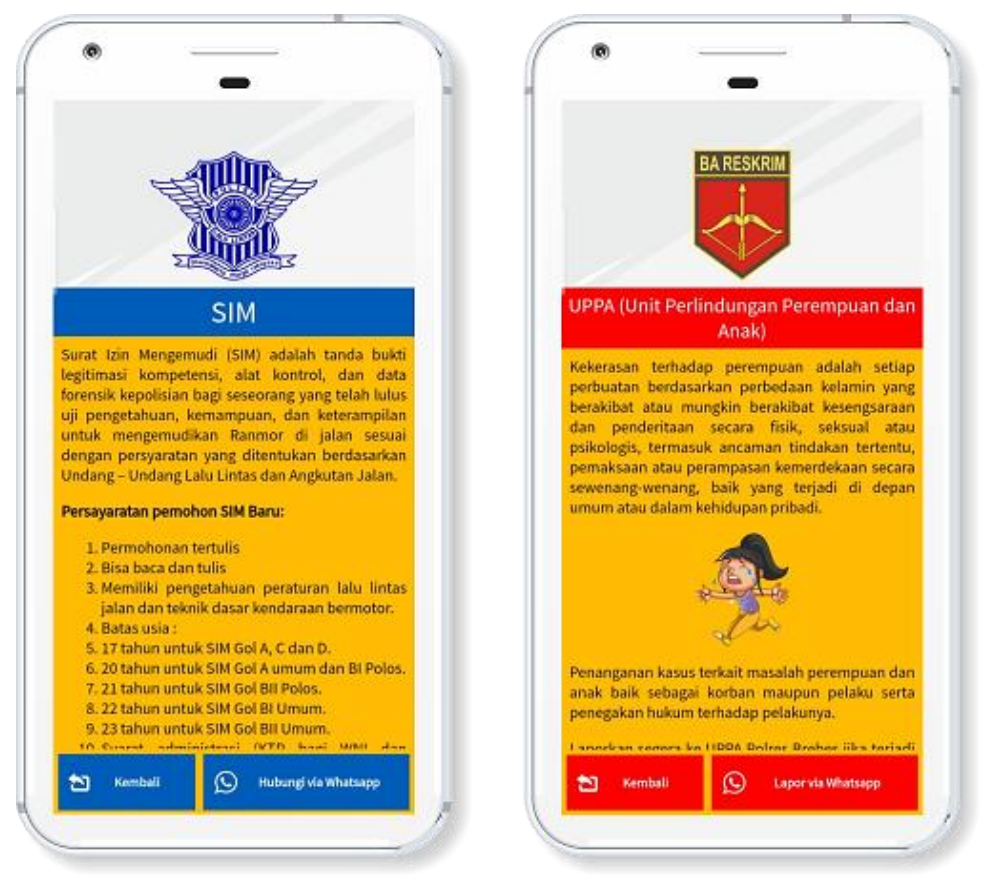

Gambar 5. Tampilan submenu: Satuan Reserse dan Polsek Sirampog Sumber: Saputro dan Haryadi, 2020 
Aplikasi "Mandalungan" telah selesai dirancang dengan visualisasi yang ditampilkan pada gambar-gambar di atas. Tahapan selanjutnya yaitu testing (pengujian). Pengujian aplikasi diawali dari uji internal yakni uji personal yang berkaitan langsung dalam hal ini yaitu Kepolisian Brebes dan ASN Pemda Brebes. Selain itu aplikasi ini sudah disosialisasikan kepada masyarakat yang bisa dilihat pada gambar 9. Pengujian kepada masyarakat yang lebih luas menjadi bahan penelitian selanjutnya sehingga aplikasi ini bisa digunakan oleh penduduk kabupaten Brebes.

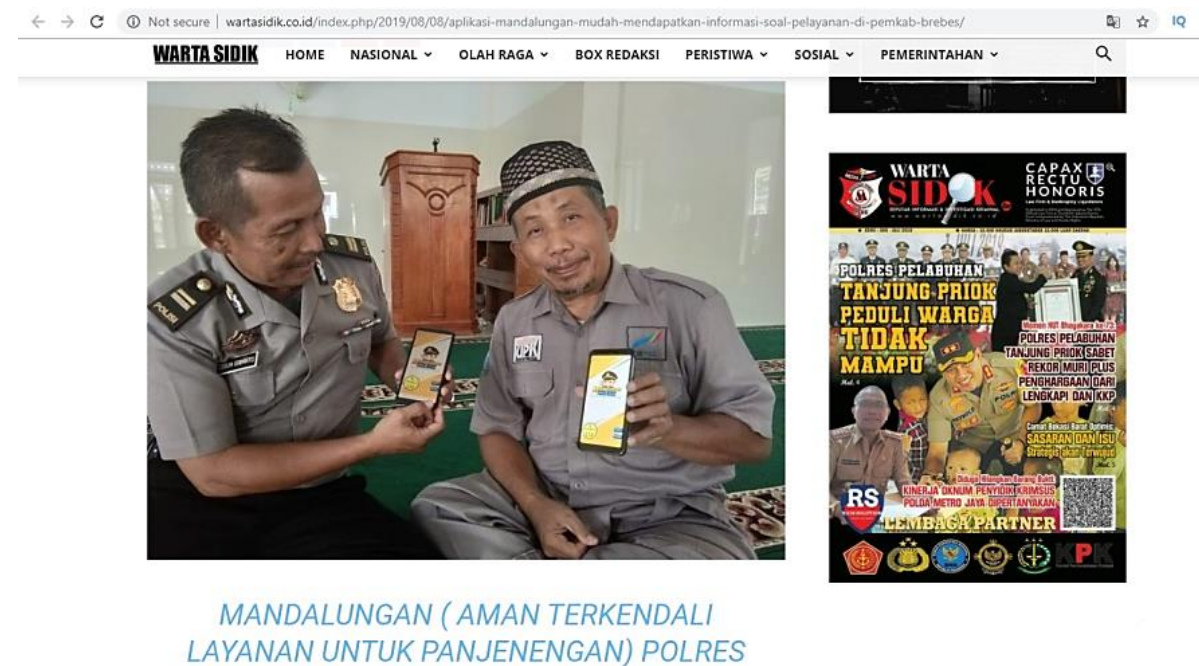

Gambar 6. Testing pada personil Polres dan ASN Sumber: Saputro dan Haryadi, 2020

Setelah aplikasi diujikan kepada pihak yang berkepentingan terhadap aplikasi ini, berikutnya yaitu distribution (publikasi dan penyebaran aplikasi). Aplikasi diluncurkan di playstore dan telah didaftarkan. Aplikasi "Mandalungan" ini dapat diunduh secara gratis oleh masyarakat dan dapat dipasang di masingmasing smartphone sehingga bisa dimanfaatkan secara efektif, efisien, serta masif. Selain itu, agar aplikasi ini bisa tersebar semakin luas, pihak kabupaten Brebes juga melakukan promosi secara intens melalui saluran-saluran resmi meliputi: sosial media, radio, koran, serta media lain. 


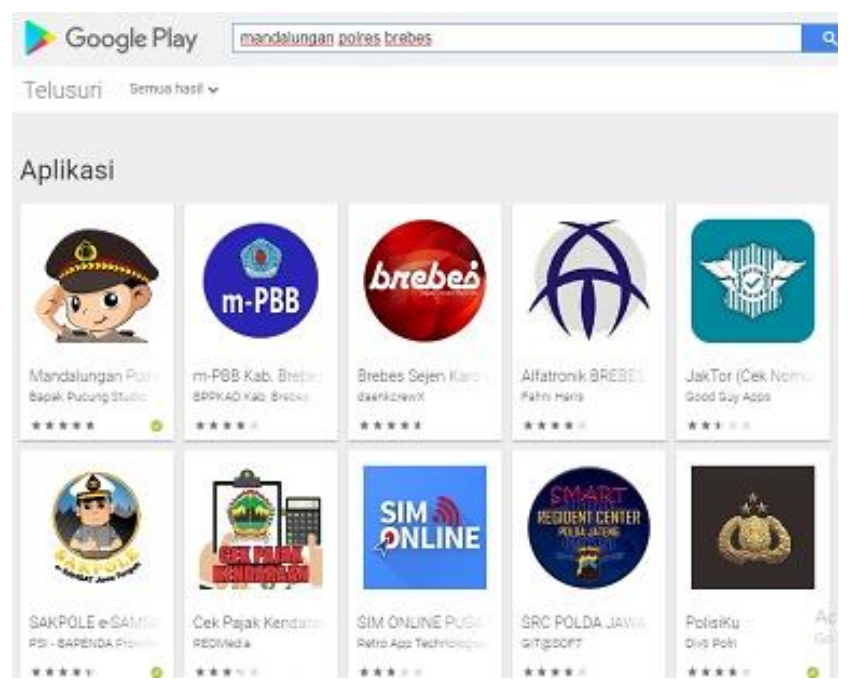

Gambar 7. Distribution aplikasi pada playstore untuk smartphone android OS Sumber: Saputro dan Haryadi, 2020

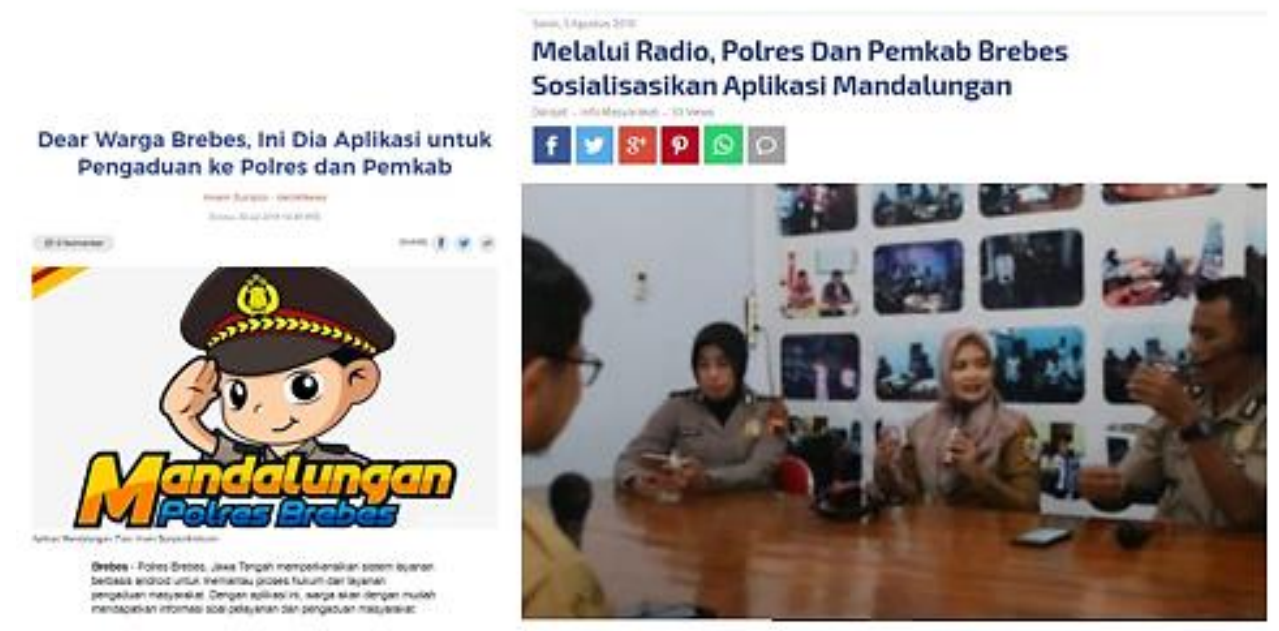

Gambar 8. Sosialisasi aplikasi "Mandalungan" ke masyarakat secara online dan offline Sumber: Saputro dan Haryadi, 2020

Perancangan aplikasi mobile "Mandalungan" menggunakan metode MDLC merupakan langkah yang tepat, karena setiap tahap harus jelas, detail, dan terstruktur untuk menghindari adanya mispersepsi sehingga aplikasi yang dihasilkan sesuai dengan konsep yang ditentukan sebelumnya yaitu untuk memenuhi kebutuhan masyarakat terkait pelayanan yang ditujukan kepada Polres, Polsek, serta Pemda Kabupaten Brebes. 


\section{KESIMPULAN}

Berdasarkan uraian di atas, dapat diambil kesimpulan bahwa aplikasi layanan "Mandalungan" merupakan salah satu bentuk peningkatan pelayanan publik yang memudahkan masyarakat, gratis diunduh di playstore, mudah dioperasikan di smartphone, serta komitmen jajaran Polres dan Pemda Brebes dalam menindaklanjuti laporan yang masuk secara respon cepat. Hal tersebut merupakan harapan ideal masyarakat terhadap kinerja aparat daerah. Berdasarkan hasil pengujian aplikasi kepada masyarakat, tidak ditemukan adanya kendala dan masyarakat memberikan apresiasi kepada pihak Polres dan Pemda Kabupaten Brebes yang dibuktikan dengan review di playstore.

Adapun penelitian ini masih memiliki kekurangan khususnya dalam hal perancangan sistem navigasi atau User Interface yang mana banyak submenu yang ditampilkan di dalam aplikasi. Selain itu, aplikasi "Mandalungan" ini menggabungkan tiga lembaga sekaligus yakni: Polres, Polsek dan Pemda; sehingga menunya menjadi banyak dan cukup membingungkan pengguna khususnya masyarakat awam yang belum terbiasa mengoperasikan smartphone. Penelitian ini bisa disempurnakan pada penelitian selanjutnya, yang lebih fokus merancang dan menyajikan user interace yang simpel, singkat, menarik, namun komunikatif. Juga ke depannya, aplikasi ini bisa dipecah menjadi tiga aplikasi berbeda masing-masing untuk layanan Polres, layanan Polsek dan layanan Pemda.

\section{PERNYATAAN PENGHARGAAN}

Rasa terimakasih dan penghargaan yang tinggi kami sampaikan kepada pihak Polres dan Pemda Brebes yang telah mendukung dan mendanai riset ini sehingga perancangan aplikasi “Mandalungan" dapat diwujudkan serta menjadi 
viral untuk dimanfaatkan seluruh masyarakat Brebes. Program ambulan motor dalam aplikasi ini juga mengantarkan PNS Polres Brebes, dr. Nani Yulia menerima Anugerah ASN Inspiratif 2019 dari Menpan-RB.

\section{DAFTAR PUSTAKA}

Abdurahman, H., dan Riswaya, A. R. 2014. Aplikasi Pinjaman Pembayaran Secara Kredit pada Bank Yudha Bhakti. Jurnal Computech \& Bisnis, Vol. 8 No. 2, h: 61-69

Alfarizi, M. K., dan Yanuar, Y. 2019. Survey Kepemilikan Smartphone, Indonesia Peringkat ke-24. Diakses dari: https://tekno.tempo.co/read/1181645/survei-kepemilikan-smartphoneindonesia-peringkat-ke-24/full\&view=ok, pada: 19 Desember 2019 pukul $09.15 \mathrm{wib}$

Anonim. 2019. Data Jumlah Penduduk Kabupaten Brebes. Diakses dari: http://dindukcapil.brebeskab.go.id/data/jumlah-penduduk, pada: 19 Desember 2019 pukul 08.35 wib

Anonim. 2019. INFORMASI: Sejarah Kabupaten Brebes. Diakses dari: http://www.brebeskab.go.id/sejarah kabupaten brebes, pada: 19 Desember 2019 pukul 08.30 wib

Binanto, I. 2010. Multimedia Digital: Dasar Teori dan Pengembangannya. Yogyakarta: ANDI

Binanto, I. 2013. Perbandingan Metode Pengembangan Perangkat Lunak Multimedia. Seminar RiTekTra, h. 1-7

Haryadi, T. dan Aripin, A. 2015. Melatih Kecerdasan Kognitif, Afektif, dan Psikomotorik Anak Sekolah Dasar Melalui Perancangan Game Simulasi "Warungku". Jurnal Andharupa, Vol. 1 No.2, h: 39-50

Haryadi, T. dan Ulumuddin, D. I. I. 2016. Penanaman Nilai dan Moral pada Anak Sekolah Dasar dengan Pendekatan Storytelling melalui Media Komunikasi Visual. Jurnal Andharupa, Vol. 2, No.1, h: 56-72

Raco, J. R. 2010. Metode Penelitian Kualitatif: Jenis, Karakteristik, dan Keunggulannya. Jakarta: Grasindo 
Razi, A., Mutiaz, I. R., dan Setiawan, P. 2018. Penerapan Metode Design Thinking pada Model Perancangan UI/UX Aplikasi Penanganan Laporan Kehilangan dan Temuan Barang Tercecer. Jurnal Demandia, Vol. 3 No. 2, h: 75-93

Rokhman, N., dkk. 2018. Perancangan Aplikasi Media Pembelajaran Melukis Bangun Ruang Berbasis Android. Jurnal Demandia, Vol. 3 No. 1, h: 116-126

Saputro, G. E., Haryadi, T., dan Yanuarsari, D. H. 2016. Perancangan Purwarupa Komik Interaktif Safety Riding Berkonsep Digital Storytelling. Jurnal Andharupa, Vol. 2 No. 2, h: 195-206

Siregar, M dan Permana, I. 2016. Rancang Bangun Aplikasi Berbasis Mobile Untuk Navigasi Ke Alamat Pelanggan TV Berbayar. Jurnal Rekayasan dan Manajemen Sistem Informasi, Vol.2 No.1

Suprianto. 2019. Polres Brebes Gabungan Gelar Razian Malam Hari. Diakses dari: http://rri.co.id/purwokerto/post/berita/738975/daerah/polres brebes g abungan gelar razia malam hari.html, pada: 19 Desember 2019 pukul 08.45 wib

Vaughan, T. Multimedia: Making It Work. Sixth Edition. McGraw-Hill Companies. 